\title{
McDougall kontra Maciver
}

\section{HOZZÁSZÓLÁS PIERRE LÉVY „AZ ÉRTELMISÉG ÚJ FELELŐSSÉGE A KOMMUNIKÁCIÓ KORÁBAN” CÍMÜ ÍRÁSÁHOZ}

\section{Szerzői információ:}

Z. Karvalics László

Történész, az információs társadalom kutatója a Szegedi Tudományegyetem Könyvtártudományi Tanszékének tanszékvezetố egyetemi docense, az ITTK (Információs Társadalom- és Trendkutató Központ) volt igazgatója, 2006-tól örökös tiszteletbeli elnöke. Számos kurzust dolgozott ki az információs társadalommal kapcsolatos ismeretek oktatásához, e tárgyban több szakkönyv és tanulmány szerzóje. A Kar Kiváló Oktatója (1999), Széchenyi-ösztöndíjas (2000-tốl). Fontosabb könyvei: Fogpiszkáló a hálózaton (2000), Az információs társadalom keresése (2002), Információ, társadalom, történelem (2003), Bevezetés az információtörténelembe (2004).

E-mail: zkl@itm.bme.hu

M

Á

C

$\mathbf{I}$

ó

$\mathbf{S}$

$\mathbf{T}$

Á

$\mathbf{R}$

S

A

D

Így hivatkozzon erre a cikkre:

Z. Karvalics László. „McDougall kontra Maciver”.

Információs Társadalom VIII, 4. szám (2008): 43-45.

https://dx.doi.org/10.22503/inftars.VIII.2008.4.9

\section{$\Longleftarrow$}

A folyóiratban közölt müvek

a Creative Commons Nevezd meg! - Ne add el! - Így add tovább! 4.0

Nemzetközi Licenc feltételeinek megfelelően használhatók. 
Z. Karvalics László

\section{McDougall kontra Maciver: ember, csoport és tudat}

\section{Bevezetés}

William McDougall, a brit szociálpszichológia egyik megalapítója és legtermékenyebb képviselôje 1920-ban jelentette meg a csoporttudatról (Hunyady György szóhasználatával: csoportszellemiségról) ${ }^{1}$ szóló könyvét (The Group Mind. G. P. Putnam \& Sons). Ekkor már egészen pontosan negyedszázados volt az a diskurzus, amelyet Gustave Le Bon késóbb számos kiadást megért és kezdettól fogva viták kereszttüzében álló munkája, A tömegek lélektana indított el 1895-ben, ${ }^{2}$ de még mindig erốsen foglalkoztatta a pszichológusokat. Nem véletlen, hogy Sigmund Freud is nagyjából ugyanekkor tette le a garast, ${ }^{3}$ és hogy számtalan alakváltozatban a harmincas évek végéig vissza-visszatérően népszerú téma maradt a „tömegek”és a „tudatok” közötti kapcsolatok fürkészése. A ,tömegnek” az a képe, amely miatt a figyelem középpontjába került, az ipari korszak új kontroll-és konfliktusstruktúráinak terméke a nagyüzemekkel és a politikai renddel az egyik oldalon, az utcát cselekvési térré változtató munkásmozgalommal, a szakszervezetekkel, a nómozgalmakkal és az agrármozgalmakkal a másikon. Ennek a „mindennapi élményként megélt" tömegnek az irodalmi, ideológiai és/vagy tudományos percepciója sokfajta megközelítést tett lehetóvé, a felszabadító erejú érzelmi azonosulástól ${ }^{4}$ az alaktalan rettegésig. Ráadásul új tartalommal telt meg az elsố világháború idején, majd azt követően, ahogyan a (para)militarista máz és a gigantizmus a bontakozó szélsójobb utcai demonstrációinak állandó kęllékévé vált.

Mindeközben azonban komoly átalakuláson és differenciálódáson ment át maga a problématér és az a fogalmi, ill. funkcionális keret, amelyben a szerzók a kérdéseiket felvetik. A pszichológia kiforratlan kategóriarendszere miatt az irodalom korai darabjainak naiv-romantikus fogalmi nyelvében, az olvasóborzongató extremitásokban és az argumentáció esetlegességében tükröződő módszertani és tudományos bizonytalanság lassan átadta a helyét egy szigorúbb, leíróbb elméleti-rendszerezó pozíciónak, utat nyitva a szociológiai szempontok megerósödésének. Evvel párhuzamosan Le Bon világa le is került a napirendról, ${ }^{5}$ az intézményesedéstôl magabiztosabbá váló szakmai múhelyek

\footnotetext{
${ }^{1}$ Hunyady György: A nemzetek jellege és a nemzeti sztereotípiák (előadás a Mindentudás Egyetemén) http://www.mindentudas.hu/doc/hunyady_nyomtathato.rtf

${ }^{2}$ Psychologie des foules. Paris, Felix Alcan.

${ }^{3}$ Group psychology and the analysis of the ego, 1921. Magyarul: Tömeglélektan és énanalízis. Budapest: 1995, Cserépfalvi.

${ }^{4}$ Gondoljunk csak József Attila Tömeg címü versére (1930). „A tömeg /.../ járó erdố rengeteg/.../ Világ, bekap a tömeg! / .. / nem fogja polgári ravaszság, / fölrugja milliónyi láb, - / hú! tömegek, tovább! tovább!"

${ }^{5}$ Elsôsorban Floyd Henry Allport, a kibontakozó amerikai szociálpszichológia iskolateremtő tekintélye (Social Psychology. Boston, 1924, Houghton Mifflin), a tudat társas vonatkozásainak korai rendszerezóje az, aki nagyon határozott állításokkal teszi szalonképtelenné a csoportszintû lelki jelenségek vizsgálatát, axióma-
} 
megkezdték árnyalt, többdimenziós csoportdefiníciókkal helyettesíteni a „tömeg” valójában „,csürhe, csőcselék” értelemben használt fogalmát, ${ }^{6}$ és evvel el is illant az az izgalom, amely az utca ad hoc tömegeinek cselekvését jellemzó, zavarba ejtố szinkronicitást egy „,csoportlény” rendszerszintjére emelt „csoporttudat” tételezésével igyekezett leírhatóvá tenni és megmagyarázni.

A történet azonban nem záródik le ezen a ponton. Edward Bernays, Freud bécsi születésú unokaöccse, aki 1919-ben nyitotta meg New York-i irodáját, a „,tömegbefolyásolás” mesterségének professzionális szintre emeléséhez használta kiindulópontnak a csoporttudat irodalmát: „Ha megértjük a csoporttudat mechanizmusait és motívumait, lehetôvé válik a tömegek ellenőrzése és irányítása, megfelelve azon szándékunknak, hogy erról ók ne szerezzenek tudomást." ${ }^{7}$ Ezen az áttételen keresztül a csoporttudat egykori irodalma napjainkban is élő hagyomány, mert a médiaipar döntéshozói, a nagyvállalatok kommunikációs hadoszlopai és a politikai marketing királycsinálói túlnyomórészt a mai napig könnyen befolyásolható foules-t látnak a fogyasztók és a választók tömegeiben, és választásaikat sokkal inkább alapozzák a Le Bontól kölcsönzött primitív ösztönlény képére, mint a sokkal differenciáltabb, korszerú szociálpszichológiai modellekre.

De térjünk vissza McDougallre és fö múvére. William Howard Johnson Tuvidor MacBeth Jenny McDougall (1871-1938) még Angolföldön szerzett magának hírnevet, ${ }^{8}$ olyannyira, hogy néha egyenesen a mai szemmel sokkal korszerúbbnek és meghatározóbbnak tûnő Tarde mellett emlegetik a pszichológiatörténeti felsorolásokban, a társulási ösztön (,,nyájösztön”), ${ }^{9}$ a viselkedés alapegységének tekintett „visszacsatolási hurok”, ill. a viselkedés „,célra irányultsága” fogalmának megalkotójaként. ${ }^{10}$

Amikor azonban az elsố világháború után az elsố pszichológiai tanszék megalakul az Egyesült Államokban, McDougall átteszi a székhelyét a Harvardra, és azonnal komoly szakmai kihívás elé kerül: a bevándorlási kvóták megszabásában számítanak a szakértôi segítségére, ez vezeti korábbi tételeinek ,alkalmazott” továbbfejlesztéséhez, egy tudományosnak szánt, korábban csak „esszéisztikus formában létezô” nemzetkarakterológia megalkotásához, amelyben „,az egyes nemzetek jellemzésén, leírásán, tulajdonságokkal való felruházásán túl megpróbálta azokat a módszertani elveket kidol-

ként szögezve le, hogy a kutatás tárgya kizárólag az egyén rendszerszintje lehet (amely természetesen társas környezetbe van beágyazva). Hasonlóképpen foglal állást Everett Dean Martin is: „I don't believe there is any common or group mind, but that crowd mentality is a kind of psychosis which happens to a number of people simultaneously." The Conflict of the Individual and the Mass in the Modern World. New York, 1932, Henry Holt and Company, VIII. fejezet: A Diagnosis of crowd mentality, 186-187.

${ }^{6}$ Joussain, André: Psychologie Des Masses (1937, Ernest Flammarion Éditeur) címú könyvének legelsô fejezete nem véletlenül kezdődik a LeBon-féle foules és az absztraktabb masses közötti különbségtétellel.

${ }^{7}$ Propaganda. New York, 1928, 47-48. Bernays, aki a public relations (PR) és a közvélemény-kutatás úttörôjének számít, késóbb döbbenten értesült róla, hogy Goebbels éppen az ô Crystallizing Public Opinion címú könyvét használta sorvezetônek a németországi zsidók clleni lejárató kampányaihoz.

${ }^{8}$ Első ,bestsellerei” - Body and Mind (1911), Psychology: the study of behaviour (London, 1912, Williams and Norgate) - mellett leginkább azzal a szintetikus bevezetố múvével szerzett magának hírnevet, amelynck még életében igen sok újrakiadása volt: az An Introduction to Social Psychology 1. kiadása 1908-ban, 23. kiadása 1936-ban jelent meg (London, Methuen).

${ }^{9}$ Maurice Reuchlin: A pszichológia története. Bp., 1987, Akadémiai Kiadó, 127-128.

${ }^{10}$ Elizabeth R. Valentine: Fogalmak és nézôpontok a pszichológiában. Bp., 1988, Gondolat. 
gozni, amelyeket követve egy kultúrát ilyen szempontból jellemezhetünk". "Az 1920-as Group Mind ennek a törekvésnek a jegyében születik meg, de ehhez bevezetésként a szerzőnek össze kell foglalnia mindazt, amit a csoporttudat természetéról korábban írt és gondolt.

Itt azonban nem tekinthet el attól, hogy a csoporttudat gondolatának közben nagyhatású és befolyásos (ráadásul: skót) bírálója támadt, Robert Morrison Maciver (más írásmód szerint: MacIver) személyében, aki friss könyvében (Community. London, 1917) megsemmisítoónek szánt bírálatban részesítette McDougall elméletét. A Group Mind egész bevezetố fejezete ezért voltaképpen egyetlen szenvedélyes védóbeszéd az „individuum feletti tudatossági szint” (super-individual consciousness) mellett, amely ugyanakkor malíciózus vádbeszéd is Maciver „szedett-vedett” és önellentmondásokkal tarkított érvelése ellen.

R. M. Maciver (1882-1970) kétségkívül nagy szálka volt McDougall szemében. 1915-ben a szociológia és a politika határvidékein kalandozó tudós Edinburgh, Oxford és Aberdeen után az észak-amerikai kontinensre, Torontóba költözött, mégpedig a politikatudományi tanszékre (hogy azután késóbb majd' negyedszázadon át a New York-i Columbia Egyetem politikai filozófia és szociológia professzora legyen). Maciver a szociológiai kánon része lett, ${ }^{12}$ számos standard szöveggyứjtemény szereplôje, ill. gondozója. Legtermékenyebb és legmaradandóbb kategóriája, a social causation a társadalmi változás (social change) oksági viszonyait boncolgatja, fó múve idevonatkozó nézeteit summázza. ${ }^{13}$ Leginkább idótálló munkájának mai szemmel mégis az 1947-ben kiadott The Web of Government túnik: ebben a társadalmi változást a kormányzatra alkalmazva annak kritikai szerepét emeli ki, amellyel képes az innovációk különböző hatásait facilitálni és moderálni.

McDougall mindvégig korrekt, érvelő vitát folytat Maciverrel, nem esik az argumentatio ad hominem hibájába. És noha álláspontja kihullott az idő rostáján, a Group Mind bevezetésének a skót vitapartner gondolataival viaskodó hosszú oldalai különösen izgalmas tudománytörténeti tanulságokat rejtenek. Hogy melyek ezek, az kiderül a szövegközlést követố tanulmányból.

\footnotetext{
${ }^{11}$ Hunyady: i. m. Hunyady nyomán feltételezhetjük, hogy McDougall szakértôi munkája elősegítette azt, hogy „diszkriminatív döntések sora” szülessen, az angolszászok, az „európaiak”, a szlávok és az ázsiaiak esetében eltérố megítélésen alapuló eltérő feltételekkel.

${ }^{12}$ Címszó például Ed Stephan szociológiai naptárjában (Sociology Calendar) http://www.ac.wwu.edu/ stephan/calendar.html

${ }^{13}$ Social Causation. Boston, 1942.
} 